Article

\title{
Vemurafenib and Rituximab in Patients with Hairy Cell Leukemia Previously Treated with Moxetumomab Pasudotox
}

\author{
Tadeusz Robak ${ }^{1,2, *(D)}$, Agnieszka Janus ${ }^{2}$, Krzysztof Jamroziak ${ }^{3}$, Enrico Tiacci ${ }^{4, \dagger}$ and Robert J. Kreitman ${ }^{5,+}$ \\ 1 Department of Hematology, Medical University of Lodz, 93-510 Lodz, Poland \\ 2 Copernicus Memorial Hospital, 93-510 Lodz, Poland; agnieszka_janus@poczta.onet.pl \\ 3 Department of Hematology, Transplantation and Internal Medicine, Medical University of Warsaw, \\ 02-097 Warsaw, Poland; krzysztof.jamroziak@wp.pl \\ 4 Institute of Hematology, University and Hospital of Perugia, 06132 Perugia, Italy; enrico.tiacci@unipg.it \\ 5 Laboratory of Molecular Biology, Clinical Immunotherapy Section, National Cancer Institute, \\ National Institutes of Health, 9000 Rockville Pike, Bethesda, MD 20892, USA; kreitmar@mail.nih.gov \\ * Correspondence: robaktad@csk.umed.lodz.pl; Tel.: +48-42-689-5191; Fax: +48-42-689-5192 \\ + These authors contributed equally.
}

Citation: Robak, T.; Janus, A.; Jamroziak, K.; Tiacci, E.; Kreitman, R.J. Vemurafenib and Rituximab in Patients with Hairy Cell Leukemia Previously Treated with Moxetumomab Pasudotox. J. Clin. Med. 2021, 10, 2800. https:// doi.org/10.3390/jcm10132800

Academic Editor: Francesco Albano

Received: 29 May 2021

Accepted: 22 June 2021

Published: 25 June 2021

Publisher's Note: MDPI stays neutral with regard to jurisdictional claims in published maps and institutional affiliations.

Copyright: (c) 2021 by the authors. Licensee MDPI, Basel, Switzerland. This article is an open access article distributed under the terms and conditions of the Creative Commons Attribution (CC BY) license (https:// creativecommons.org/licenses/by/ $4.0 /)$.

\begin{abstract}
The purine nucleoside analogues cladribine and pentostatin are highly-active first-line therapeutic treatments for hairy cell leukemia (HCL), resulting in complete response rates of $80 \%$ to $90 \%$. However, HCL patients continue to relapse, and sooner or later, most require subsequent lines of treatment. This report presents the cases of four relapsed patients with classic HCL who were treated with vemurafenib (mostly at the low dose of $240 \mathrm{mg}$ twice daily for 16 weeks) combined with rituximab after the failure of several lines of therapy including cladribine with or without rituximab and moxetumomab pasudotox. Two patients achieved minimal residual disease negative complete response after combined treatment with vemurafenib and rituximab, with a hematologic response ongoing after 38 months from the end of treatment in one patient and a relapse of cytopenias occurring after 13 months in the other patient. A third patient normalized her blood counts and this hematologic response, which was not evaluated in the bone marrow at the end of treatment, was lost after 18 months. The last patient died due to infection and multi-organ failure, too early to verify response to vemurafenib. Two patients who had relapsed after vemurafenib and rituximab derived meaningful clinical benefit from retreatment with the same agents, but eventually relapsed again and started indefinite therapy with dabrafenib and trametinib leading to normalization of the blood counts (despite heavy bone marrow infiltration in the only patient so far evaluable in that regard). The outcomes of these cases indicate that novel targeted agents and, in particular, vemurafenib, combined with rituximab, improve the prognosis of HCL patients, even those heavily pretreated with PNAs and moxetumomab pasudotox.
\end{abstract}

Keywords: BRAF; cladribine; dabrafenib; hairy cell leukemia; moxetumomab pasudotox; rituximab; vemurafenib

\section{Introduction}

Hairy cell leukemia (HCL) is a rare chronic B-cell neoplasm originating from a mature B lymphocyte; it is characterized by marked splenomegaly, progressive pancytopenia, and infiltrations of the bone marrow (BM) with reactive marrow fibrosis [1,2]. The annual incidence of HCL is estimated to be 0.3 cases per 100,000 and the disease constitutes $2-3 \%$ of all leukemias [3,4]. A diagnosis of HCL is established by a combination of peripheral blood smear, flow cytometry and bone marrow biopsy. Recently, it has been found that the BRAF p.V600E somatic mutation is present in $90 \%$ to $100 \%$ of patients with classic $\mathrm{HCL}$, and this has been described as a disease-defining genetic event [5]. The drugs of choice in the treatment of HCL are purine nucleoside analogs (PNAs), cladribine (2-CdA) and pentostatin (DCF) [1,2]. These agents induce durable complete response (CR) in more 
than $70 \%$ of first line patients and are also effective in re-induction therapy. However, patients continue to relapse, with median response duration of 8-10 years, and most experience several relapses [6,7]. Repeated treatments with the same PNA are effective in some patients, but the $\mathrm{CR}$ rate and response duration following subsequent courses typically shorten with subsequent treatments [7-9]. Patients who relapse within two or three years after the first PNA treatment have worse prognosis and lower likelihood of a second durable CR achievement. In addition, in some cases, the disease is refractory to PNA therapy. The median duration of response to second line 2-CdA monotherapy is $2-9$ years $[8,9]$.

Moxetumomab pasudotox (Moxe, LUMOXITI ${ }^{\mathrm{TM}}$, AstraZeneca, Wilmington, DE, USA) is a recombinant immunotoxin composed of the Fv fragment of an anti-CD22 monoclonal antibody fused to a 38-kDa fragment of Pseudomonas exotoxin (PE38) [10]. Its approval was based on phase 1 and phase 3 clinical trials evaluating the safety and efficacy of the drug in relapsed/refractory HCL [10-12]. The BRAF V600E mutation inhibitors vemurafenib and dabrafenib also exhibit remarkable activity in multiply-relapsed and refractory patients with classic HCL [13-15]. Combining BRAF inhibitors with anti-CD20 monoclonal antibodies or MEK inhibitor as therapy can be even more effective than using the BRAF inhibitors alone $[16,17]$.

However, the optimal drug sequencing for relapsed/refractory HCL remains unestablished. The present study reviews data from four heavily-pretreated HCL patients who received combination therapy of vemurafenib and rituximab after the failure of Moxe.

\section{Materials and Methods}

This retrospective study examines the cases of four patients with classic HCL who were treated with vemurafenib and rituximab following relapse after Moxe. Their clinical records were identified in the hospital registry at Copernicus Memorial Hospital (Lodz, Poland). All patients were found to be positive for BRAF p.V600E, as indicated by conventional AS PCR for the BRAF V600E mutation; this has an analytical sensitivity $0.1 \%$ mutated allele [18]. AE were evaluated according to Common Terminology Criteria for Adverse Events (CTCAE) Version 5.0. Common Terminology Criteria for Adverse Events (CTCAE), Version 5 Ed, National Cancer Institute, 2017 (http:/ / evs.nci.nih.gov / ftp1/CTCAE/About.html; accessed on 21 June 2021) Response to therapy was evaluated using the consensus guidelines for the diagnosis and management of patients with HCL [1]. All procedures performed in studies involving human participants were in accordance with the ethical standards of the institutional and/or national research committee and with the 1964 Helsinki Declaration and its later amendments or comparable ethical standards.

\section{Results}

The demographics, prior treatments and clinical outcomes of the four patients are summarized in Table 1. 
Table 1. Patient characteristics and treatment results.

\begin{tabular}{|c|c|c|c|c|c|c|}
\hline & Age at Diagnosis/Sex & Therapies Before Moxe * & Moxe Treatment * & Vem + $\mathbf{R}$ Treatment & Response to $\mathrm{V}+\mathrm{R}^{*}$ & Subsequent Treatment * \\
\hline 1 & $28 / \mathrm{F}$ & $\begin{array}{l}\text { 1. 2-CdA (PR; } 21 \mathrm{~m}) \\
\text { 2. 2-CdA + R (PR; } 6 \mathrm{~m}) \\
\text { 3. IFN- } \alpha(\mathrm{PR} ; 17 \mathrm{~m}) \\
\text { 4. } 2-\mathrm{CdA}(\mathrm{PR} ; 26 \mathrm{~m})\end{array}$ & $\begin{array}{l}40 \mu \mathrm{g} / \mathrm{kg} \text { iv } \times 3 \text { every } \\
28 \text { days } \times 6(\mathrm{PR} ; 22 \mathrm{~m})\end{array}$ & $\begin{array}{c}\text { Vem } 240 \mathrm{mg} \text { BID for } \\
16 \text { weeks }+\mathrm{R} \\
375 \mathrm{mg} / \mathrm{m}^{2} / \mathrm{d} / \text { iv } / \text { every } \\
2 \text { weeks } \times 8\end{array}$ & $\begin{array}{l}\text { MRD negative } C R \text { (ongoing } \\
\text { at } 38 \mathrm{~m} \text { ) }\end{array}$ & None \\
\hline 2 & $33 / \mathrm{F}$ & $\begin{array}{l}\text { 1. } 2-\mathrm{CdA} \times 2 \text { courses }(\mathrm{PR} ; 15 \mathrm{~m}) \\
\begin{array}{l}\text { 2. IFN- } \alpha(\mathrm{NR}) \\
\text { 3. } 2-\mathrm{CdA}+\mathrm{R}(\mathrm{PR} ; 6 \mathrm{~m})\end{array}\end{array}$ & $\begin{array}{l}40 \mu \mathrm{\mu g} / \mathrm{kg} \text { iv } \times 3 \text { every } \\
28 \text { days } \times 6(\mathrm{PR} ; 11 \mathrm{~m})\end{array}$ & $\begin{array}{l}\text { Vem } 960 \mathrm{mg} \text { BID for } \\
2 \text { weeks, (intolerance), dose } \\
\text { reduction to } 240 \mathrm{mg} \text { BID for } \\
14 \text { weeks }+\mathrm{R} \\
375 \mathrm{mg} / \mathrm{m}^{2} / \mathrm{d} / \text { iv } / \text { every } \\
2 \text { weeks } \times 8\end{array}$ & $\begin{array}{l}\text { Hematologic response } \\
\qquad(18 \mathrm{~m})\end{array}$ & $\begin{array}{c}\text { Vem } 240 \mathrm{mg} \text { BID for } 16 \text { weeks }+\mathrm{R} \\
375 \mathrm{mg} / \mathrm{m}^{2} / \mathrm{d} / \text { iv } / \text { every } 2 \text { weeks } \times 8 \text { (MRD positive } \\
\mathrm{CR} ; 17 \mathrm{~m} \text { ). Dabrafenib }(75-150 \mathrm{mg} / \mathrm{d} \text { BID po) + } \\
\text { trametinib } 2 \mathrm{mg} / \text { day indefinitely (ongoing } \\
\text { hematologic remission; } 2 \mathrm{~m} \text { ) }\end{array}$ \\
\hline 3 & $53 / \mathrm{M}$ & $\begin{array}{l}\text { 2. } 2-\mathrm{CdA}(\mathrm{CR} ; 27 \mathrm{~m}) \\
\text { 3. } 2-\mathrm{CdA}(\mathrm{CR} ; 98 \mathrm{~m})\end{array}$ & $\begin{array}{l}40 \mu \mathrm{g} / \mathrm{kg} \text { iv } \times 3 \text { every } 28 \mathrm{~d} \\
\times 6(\text { CR MRD-; } 17 \mathrm{~m})\end{array}$ & $\begin{array}{c}\text { Vem } 240 \mathrm{mg} \text { BID for } \\
16 \text { weeks }+\mathrm{R} \\
375 \mathrm{mg} / \mathrm{m}^{2} / \mathrm{d} / \text { iv } / \text { every } \\
2 \text { weeks } \times 8\end{array}$ & MRD negative CR (13 m) & $\begin{array}{c}\text { Vem } 240 \mathrm{mg} \text { BID for } 7 \text { weeks }+\mathrm{R} \\
375 \mathrm{mg} / \mathrm{m} 2 / \mathrm{d} / \mathrm{iv} / 4 \text { doses; Splenectomy (PR; } 5 \mathrm{~m} \text { ) } \\
\text { Vem } 240 \mathrm{mg} \text { BID for } 16 \text { weeks }+\mathrm{R} \\
375 \mathrm{mg} / \mathrm{m} 2 / \mathrm{d} / \mathrm{iv} / \text { every two weeks } \times 8 \\
\text { (hematologic remission; } 4 \mathrm{~m}) \\
\text { Dabrafenib (75- } 150 \mathrm{mg} / \mathrm{d} \text { BID po) }+ \text { trametinib } \\
2 \mathrm{mg} / \text { day indefinitely (hematologic remission; } 10 \mathrm{~m} \text { ) }\end{array}$ \\
\hline 4 & $45 / \mathrm{M}$ & $\begin{array}{l}\text { 1. 2-CdA (PR; } 22 \mathrm{~m}) \\
\text { 2. 2-CdA (PR; } 27 \mathrm{~m}) \\
\text { 3. 2-CdA (CR; } 144 \mathrm{~m}) \\
\text { 4. 2-CdA (PR; } 23 \mathrm{~m}) \\
\text { 5. 2-CdA (PR; } 16 \mathrm{~m}) \\
\text { 6. } 2 \text {-CdA + R (PR; } 24 \mathrm{~m})\end{array}$ & $\begin{array}{c}40 \mu \mathrm{g} / \mathrm{kg} \mathrm{IV} \times 3 \text { every } 28 \mathrm{~d} \\
\times 6(\mathrm{CR} \text { MRD+;38 m })\end{array}$ & $\begin{array}{l}\text { Vem } 960 \mathrm{mg} \text { BID for three } \\
\text { weeks, Only } 1 \text { dose of R due } \\
\text { to infection }\end{array}$ & Not evaluable & $\begin{array}{l}\text { Died after three weeks of treatment with } \\
\text { vemurafenib due to pneumonia and septic shock }\end{array}$ \\
\hline
\end{tabular}

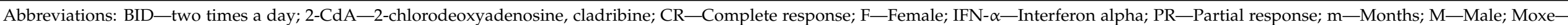

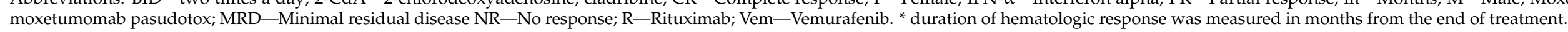


Before Moxe initiation, all patients had been previously treated with at least three lines and one patient with six lines of therapy. Previous treatments included 2-CdA monotherapy, 2-CdA combined with rituximab, and IFN- $\alpha$. The median time from diagnosis to Moxe initiation was 112 (range 28-258) months. All four patients were treated with Moxe at 40 micrograms on days 1,3 , and 5 of each 28 -day cycle for up to five to six courses within a phase 3 clinical trial. Two patients achieved a CR and two PR, with hematologic remission lasting 11 to 38 months from the end of treatment (Table 1). None of the four patients experienced serious adverse reactions, such as capillary leak syndrome or hemolytic uremic syndrome. In all four patients, vemurafenib plus rituximab was given as the subsequent treatment after Moxe due to HCL progression, with no serious adverse reactions from this combo regimen. One patient (No 4), who started vemurafenib at the dose of $960 \mathrm{mg}$ BID, was not evaluable as he died early of a severe infection (after having survived for 302 months from HCL diagnosis). In the other three patients, the drug was given at the low dose of $240 \mathrm{mg}$ BID for 16 weeks in combination with rituximab $\left(375 \mathrm{mg} / \mathrm{m}^{2} / \mathrm{d} / \mathrm{iv}\right)$ every two weeks for eight doses. Two patients achieved MRD negative CR with hematologic remission that was ongoing at 38 months from the end of treatment in one case, while it was lost after 13 months in the other case. The third patient achieved a hematologic remission (with unknown bone marrow response at the end of treatment), that was lost after 18 months. The two patients who progressed after vemurafenib plus rituximab were successfully retreated with this regimen and derived clinical benefit for a duration that was similar (in one patient) and lower (in the other patient) compared to the previous course. At eventual relapse, both patients were started on indefinite dabrafenib and trametinib; one of these two patients (No. 3) regained a hematologic remission since 10 months despite persistence of marked leukemic infiltration of the bone marrow, while the other patient (No. 2) recently started treatment and achieved hematologic remission that was ongoing at 2 months.

\subsection{Case Description}

\subsubsection{Case 1}

A 28-year-old woman with pancytopenia, symptoms of hemorrhagic diathesis and splenomegaly $(160 \mathrm{~mm})$ was first seen in July 2008. A diagnosis of HCL was confirmed by immunohistochemistry and flow cytometry. Between August 2008 and April 2010 she received two lines of 2-CdA based regimens (Table 1). She relapsed again in April 2010 and second-line treatment was administered, consisting of 2-CdA and rituximab and a PR was achieved. The second relapse was noted in February 2011 and she started interferon alpha $(\mathrm{IFN}-\alpha)$ at a dose of $3 \mathrm{mln}$ IU, $3 \times$ per week given for five months, and obtained only a PR lasting until June 2012. In September 2012, fourth-line treatment with 2-CdA was applied, and again a PR was achieved. In April 2015, the fifth-line treatment was begun, with six cycles of Moxe within the phase 3 clinical trial at the National Institutes of Health (NIH) Clinical Center [11,12]. At the end of the treatment, she fulfilled the criteria for PR. In August 2017, she experienced the fifth disease relapse, with hemoglobin $(\mathrm{Hb}) 12.3 \mathrm{~g} / \mathrm{dl}$, white blood cells $(\mathrm{WBC}) 2.32 \times 10^{3} / \mu \mathrm{L}$, absolute neutrophil count (ANC) $0.83 \times 10^{3} / \mu \mathrm{L}$ and platelets (PLT) $73 \times 10^{3} / \mu \mathrm{L}$. The presence of BRAF p.V600E mutation was confirmed by AS-PCR in the PB and BM aspirate and she started treatment with vemurafenib (240 mg BID for 4 months) in combination with rituximab $\left(375 \mathrm{mg} / \mathrm{m}^{2} / \mathrm{d} / \mathrm{iv}\right)$ every two weeks for eight doses. During the treatment, she complained of diffuse arthralgia and skin rash. In response to these symptoms, concomitant treatment with prednisone $10 \mathrm{mg} / \mathrm{d} /$ orally was initiated, with success. CBC recovery was observed after one month of treatment. After the end of the therapy in January 2018 she obtained a MRD negative complete response (CR) confirmed by an assessment of the BM aspirate and flow cytometry, BM trephine biopsy and AS-PCR for BRAF p.V600E mutation in the peripheral blood (PB) and BM aspirate (with a sensitivity threshold of $0.1 \%$ mutant alleles). As of April 2021, 38 months after treatment discontinuation, the patient has remained without any evidence of the disease with normal CBC. 


\subsubsection{Case 2}

A 33-year-old woman was diagnosed with symptomatic HCL in June 2013. Between June and January 2014, she received two courses of 2-CdA, which resulted in a PR (Table 1). Subsequently, the patient relapsed, and second-line treatment with IFN- $\alpha 3 \mathrm{mln} U \times 3$ per week was administered from September 2014 to December 2014 without response. The disease progressed in January 2015, and she began third-line treatment with 2-CdA in combination with eight doses of rituximab and a PR was obtained, which lasted only six months. In September 2015, she started Moxe for six courses within a pivotal multicenter trial and again PR was achieved. In November 2016 she experienced the fourth relapse, with progressive pancytopenia including transfusion-dependent anemia and infections. In January 2017 she started the fifth-line treatment with vemurafenib $960 \mathrm{mg}$ BID and rituximab $375 \mathrm{mg} / \mathrm{m}^{2} / \mathrm{d} /$ iv scheduled every two weeks for eight doses. After the initial two weeks, the dose of vemurafenib was reduced to $240 \mathrm{mg}$ BID due to intolerance (photosensitivity, arthralgia, musculoskeletal pain, rash); treatment was continued for a further 16 weeks without any further complications. Cytopenias resolved after one month from the start of treatment. In January 2019, she was admitted to the emergency room because of fever and fatigue. Her CBC revealed WBC $0.91 \times 10^{3} / \mu \mathrm{L}$, ANC $0.54 \times 10^{3} / \mu \mathrm{L}$, $\mathrm{Hb} 8.1 \mathrm{~g} / \mathrm{dL}$ and PLT $135 \times 10^{3} / \mu \mathrm{L}$. Bone marrow aspirate and trephine biopsy confirmed the relapse of HCL. In February 2019, retreatment with $240 \mathrm{mg}$ BID vemurafenib for 16 weeks with eight doses of $375 \mathrm{mg} / \mathrm{m}^{2} / \mathrm{d} /$ iv rituximab (one dose every two weeks) was initiated. To prevent previous noted vemurafenib toxicities, $10 \mathrm{mg}$ prednisone was initiated. PB counts normalized four weeks after retreatment initiation, and a CR MRD $(+)$ was documented in a bone marrow evaluation done in October 2019 about 4 months after the end of treatment, with the BRAF p.V600E mutation present at an allele frequency of $0.085 \%$ by digital PCR. She remained in remission for 17 months. In February 2020, progression of HCL was diagnosed with pancytopenia and $80 \%$ of hairy cell involvement in BM trephine biopsy. In April 2021 she started combined therapy with dabrafenib (Tafinlar) 75-150 mg/d BID p.o. and trametinib (Mekinist) $2 \mathrm{mg} /$ day. Currently she has been maintained on these drugs for two months, achieving a hematological response.

\subsubsection{Case 3}

A 53-year-old man was first seen in our Department in July 2003 because of fever and pancytopenia. Bone marrow biopsy confirmed a diagnosis of classic HCL by immunohistochemistry and flow cytometry. Between July 2003 and April 2007 the patient achieved three courses of 2-CdA and a CR was obtained after each course (Table 1). Progression after a third course of 2-CdA was reported in 2015 and he started Moxe as a part of a phase 3 clinical trial and the patient obtained a MRD negative CR. In October 2017, he was admitted to our hospital because of anemia, thrombocytopenia, and infection. BM aspirate was consistent with $60 \%$ infiltration with HCL cells, and the presence of $B R A F$ V600E mutation was confirmed by PCR. Between November 2017 and February 2018, the patient was treated with vemurafenib (240 mg BID) and $375 \mathrm{mg} / \mathrm{m}^{2} / \mathrm{d} /$ iv rituximab every 2 weeks for eight doses. Blood counts normalized within 1 month. MRD-negative CR (at a sensitivity threshold of $0.1 \%$ mutant $B R A F-\mathrm{V} 600 \mathrm{E}$ alleles) was obtained after the end of treatment. However, the patient relapsed in February 2019, with massive splenomegaly $(320 \times 120 \mathrm{~mm})$ and pancytopenia. In March 2019 retreatment was started with vemurafenib at the dose $240 \mathrm{mg}$ BID for 7 weeks in combination with rituximab $375 \mathrm{mg} / \mathrm{m} 2 / \mathrm{iv}$ for a total of 4 doses administered every two weeks. After one month blood counts improved without, however, any reduction of splenomegaly. The patient was splenectomized in May 2019. As a result of this salvage therapy, short-termed hematological remission was obtained. In September 2019 the disease recurred with pancytopenia and gastrointestinal tract bleeding as a result of severe thrombocytopenia. In October 2019, retreatment with vemurafenib (240 mg BID) and rituximab (eight doses, one every other week) was started again and continued for 16 weeks until February 2020, without any toxicities. The CBC returned to normal at the end of the treatment. He relapsed again in June 2020 and combined 
treatment with dabrafenib (150 mg BID po) and trametinib (2 mg/day) was initiated. Two weeks later, the dose of both drugs was reduced (dabrafenib $75 \mathrm{mg}$ BID, and trametinib $2 \mathrm{mg}$ every other day) due to progressive pancytopenia. Hematologic remission was first achieved 2 months after starting treatment and was maintained until April 2021, when he developed mild thrombocytopenia and trephine biopsy showed 80\% leukemic infiltration.

\subsubsection{Case 4}

A 45-year-old man was first seen with pancytopenia and splenomegaly in June 1994. A bone marrow (BM) biopsy was consistent with diagnosis of classic HCL by immunohistochemistry and flow cytometry. Between October 1994 and May 2013 the patient was treated with five courses of $0.12 \mathrm{mg} / \mathrm{kg} / \mathrm{d} / \mathrm{iv} 2$-CdA for five days each, resulting in a PR, PR, CR CR and PR, respectively (Table 1). After the fourth relapse, in January 2016, the patient was included in the clinical trial with Moxe. Following this sixth course of treatment, BM biopsy revealed CR MRD negative. In August 2019, he was admitted to our Department with progressive pancytopenia. BM biopsy confirmed progression of HCL with $90 \%$ marrow involvement, and the BRAF p.V600E mutation was detected. Salvage treatment was initiated with vemurafenib $960 \mathrm{mg}$ orally twice a day and one dose of rituximab $\left(375 \mathrm{mg} / \mathrm{m}^{2} / \mathrm{d} / \mathrm{iv}\right)$ simultaneously with filgrastim. Considering the profound decline in ANC, rituximab was withheld. However, three weeks later, the patient developed pneumonia and septic shock with blood cultures positive for multi-resistant Pseudomonas aeruginosa and died of multi-organ failure.

\section{Discussion}

Conventional treatment with PNAs has been shown to provide a long-lasting hematological and clinical response in most patients with classic HCL. However, the patients often relapse and require multiple treatments, and may thus become refractory to re-treatment with PNAs. Fortunately, the recent introduction of novel agents has expanded the spectrum of therapy possibilities for those patients, and now, treatment options for the management of early-relapsed patients, or those refractory to PNAs, inlude IFN- $\alpha$, rituximab and Moxe [19-22]. We reviewed the records from four patients treated at Copernicus Memorial Hospital, Lodz, Poland; all received multiple lines of 2-CdA and were subsequently treated with Moxe, followed by vemurafenib combined with rituximab. In addition, two patients were treated with IFN- $\alpha$ after relapse with 2-CdA: one of them did not respond and one obtained only a PR lasting 17 months. IFN- $\alpha$ may still have a place in the treatment, but its use is currently limited, being restricted to pregnant patients and in patients presenting with neutropenia below $0.2 \times 109 / \mathrm{L}$, when the risk of infection is high $[20,21]$. Our patients received Moxe within the pivotal, phase 3 multicenter study [11,12]. All patients responded to the treatment, two with PR and two with CR, with hematologic remission lasting from 11 to 38 months after the end of treatment. These results agree with those of a previous phase 1 and phase 3 trial, which included similar patient populations (with a median of 3 prior therapies): these trials demonstrated a durable CR of $30 \%$ to $64 \%$, and an objective response rate (ORR) of $75 \%$ to $88 \%$ of the patients [10,22]. In addition, $82 \%$ to $85 \%$ of complete responders achieved MRD negativity [12,22]. Moxe has been approved by FDA for the treatment of patients with relapsed or refractory HCL after previous treatment with at least two lines of therapy, including at least one PNAs [23]. Moxe is now being tested in combination with rituximab to improve/hasten response and prevent immunogenicity.

More recently, vemurafenib, dabrafenib, trametinib and ibrutinib are currently under investigation in patients unsuitable for PNAs [13,24-29]. These agents have been proposed as relatively safe drugs, even in pretreated patients, with severe neutropenia and (in the case of BRAF inhibitors) infections. However, they are still considered "off-label" in the treatment of this disease.

In particular, the $B R A F$ inhibitor vemurafenib was evaluated in relapsed and refractory patients with classic HCL in two phase 2 multicenter studies [13]. The drug was administered at a dose of $960 \mathrm{mg}$, twice daily for a median of 16-18 weeks. The OR rates were $96 \%$ 
to $100 \%$ with CR rates of $35 \%$ to $42 \%$, and responses were obtained after a median of 8 to 12 weeks. Interestingly, while vemurafenib had been originally suggested to have similar effectiveness when used at much lower doses in a retrospective case series [14], an update of the same series expanded with additional patients showed that doses of vemurafenib lower than $480 \mathrm{mg}$ bid might have suboptimal efficacy [15]. In particular, patients who received high-dose $B R A F i$ treatment (vemurafenib $\geq 480 \mathrm{mg}$ bid, dabrafenib $\geq 150 \mathrm{mg}$ bid) demonstrated significantly longer treatment-free survival (median, 14.6 months) than patients who were treated with lower doses (median, 9.4 months). In a recently published phase 2 trial on $30 \mathrm{HCL}$ patients with a median of three prior therapies (not including Moxe; [17]), adding rituximab (8 doses, one every other week) concomitantly and subsequently to a short treatment with vemurafenib at the dose of $960 \mathrm{mg}$ bid for a total of 8 weeks produced a very high rate of complete remissions (87\%) and negativity for minimal residual disease/MRD (60\%). These deep responses translated into a durable relapse-free survival of $85 \%$ at almost 3 years of follow-up from the end of treatment. Relative dose intensity of vemurafenib was high (median of $92 \%$ ), attesting to the safety and tolerability of the $960 \mathrm{mg}$ bid dose when given for a short period ( 8 weeks in total). Receipt of a relative dose intensity $<60 \%$ seemed to be associated with treatment failure, with the caveat of the low number of these events [17].

This is the first report documenting the activity of vemurafenib plus rituximab even in the context of relapse after Moxe, including hematologic remission in all three evaluable patients and MRD-negative CR in the two patients who underwent bone marrow evaluation at the end of treatment. Relapse-free survival after the end of treatment was substantial in one case (response ongoing at 38 months, versus 22 months after previous Moxe), while it was lower but still clinically meaningful in the other two cases (18 and 13 months, comparing well with 11 and 17 months after previous Moxe, respectively). When contrasted to the clinical trial of vemurafenib plus rituximab [17], the relapse-free survival in 2 of these 3 patients may appear somewhat lower, which might be due to a higher intrinsic drug resistance of their disease relapsing even after Moxe and/or (as suggested by [15]) to a lower efficacy of the vemurafenib dose used (240 $\mathrm{mg}$ bid). In patient 3, who relapsed 13 months after obtaining a CR with no MRD detected at a threshold of $0.1 \% B R A F-\mathrm{V} 600 \mathrm{E}$ mutant alleles on conventional PCR, it is also possible that MRD was actually present below that threshold and that a more sensitive approach such as digital PCR could have identified it.

The fourth patient, who had received 7 lines of therapy over 15 years, was not evaluable as he died too early ( 3 weeks after starting vemurafenib plus rituximab) of a severe infection caused by a pre-existing deep neutropenia, which even such a high effective treatment was not expected to necessarily resolve earlier (indeed, the median time to resolution of neutropenia after vemurafenib plus rituximab is 4 weeks [17]). Nevertheless, previous reports based on small numbers of cases suggested that vemurafenib is a safe and effective drug even in patients with HCL presenting with severe neutropenia, fever and infection $[26,27,30]$.

This report also starts to address the issue of relapse after vemurafenib plus rituximab. Re-treatment with vemurafenib is an option that should be considered in this context, as exemplified by two of our cases enjoying clinical benefit from retreatment, although for a shorter duration in one case. Likewise, Liebers et al. reported rapid hematologic improvement in 17 patients retreated with $B R A F$ inhibitors (85\% previously treated with vemurafenib or dabrafenib) with at least one further BRAFi course [15]; however, the subsequent $B R A F$ inhibitor courses yielded shorter response durations than the initial treatment. Similar results were obtained with vemurafenib retreatment in clinical trials [13]. Dabrafenib is another $B R A F$ inhibitor that can be used in patients with heavily-pretreated recurrent/refractory $B R A F$ V600E-mutated HCL, including cases previously treated with vemurafenib [24]. Dabrafenib can be also combined with the mitogen-activated extracellular signal-regulated kinase (MEK) inhibitor trametinib. Kreitman et al. found combination therapy of indefinite duration (median of 17 months) based on dabrafenib (150 mg twice 
daily) with the MEK inhibitor trametinib (2 mg once daily) is effective and well tolerated in 43 relapsed/refractory HCL patients with presence of a BRAF V600E mutation [17] who were not previously treated with a BRAF inhbitor. The OR rate was $78 \%$ including $49 \%$ CRs; Grade 3/4 AEs were observed in $49 \%$ of patients. Interestingly, our two patients who relapsed after retreatment with vemurafenib plus rituxmab both regained a hematologic remission with dabrafenib plus trametinib.

We used vemurafenib for limited time as in the most previous studies of this drug $[13,14,17]$ Limited treatment duration can decrease adverse events noted with $B R A F$ inhibitors including skeletal pain, photosensitivity, skin tumors and renal toxicity. On the other hand, treatment with vemurafenib, especially in combination with rituximab induces deep, long responses making unlimited treatment redundant [17]. In addition, relapsed patients can achieve response after retreatment with the same drug $[13,15]$.

In our study, the sequence Moxe before vemurafenib plus rituximab was used. However, it is not clear today, which regimen should be used first in HCL patients relapsed after PNAs. Currently, Moxe is approved by the FDA and EMA for the treatment of relapsed HCL patients and is commercially available in the USA, whereas it is not clear whether and when it will be commercialized elsewhere. Vemurafenib or dabrafenib are not approved for this indication yet, and are used off label also in the USA, but are marketed for BRAF-mutated melanoma worldwide and the efficacy of vemurafenib plus rituximab seems higher [17] than that of Moxe [11]. For these reasons, in patients with early relapsed or refractory HCL outside of clinical trials we recommend Moxe or vemurafenib plus rituximab depending on local availability and ease of reimbursement of the respective drug(s). On the other hand, vemurafenib seems to be an effective and well-tolerated drug in neutropenic patients with infection $[26,27,29,30]$. In such patients vemurafenib or dabrafenib, if available, might be used before Moxe, as there is lesser experience with the latter drug in the setting of an active infection. However, Moxe does not directly worsen neutropenia and in fact neutropenia is usually disease-related and resolves during cycle 2. Future studies should clarify the optimal treatment sequence with these drugs in HCL patients.

\section{Conclusions}

In the coming years, targeted drugs will play a key role in standard therapy for patients with relapsed or refractory HCL after treatment with PNAs. The history of the presented cases indicates that novel targeted agents and, in particular, vemurafenib plus rituximab, improve the prognosis of HCL patients, even those who are heavily pretreated with PNAs and Moxe. However, despite the interesting perspective of targeted treatments in HCL, older options should not be forgotten, including bendamustine plus rituximab [31] and (pegylated) interferon [20]. Still, HCL remains an incurable disease in such an advanced relapsed/refractory disease setting, and the development of novel therapeutic strategies is required.

Author Contributions: T.R., A.J., K.J. and R.J.K. provided patient care; E.T. performed BRAF p.V600E testing with AS PCR. T.R., A.J., K.J., E.T. and R.J.K. collected and analyzed the results, and wrote and reviewed the paper. All authors have read and agreed to the published version of the manuscript.

Funding: The study was supported in part by grants from the Medical University of Lodz, Poland: No. 503/1-093-01/503-11-004-18, and from the Italian Ministry of Health (grant RF-2016-02362264 to ET).

Institutional Review Board Statement: This study was approved by the institutional review board at the Copernicus Memorial Hospital, Lodz, Poland.

Informed Consent Statement: Informed consent was obtained from the patients included in the study.

Data Availability Statement: The data presented in this study are available from the corresponding author for request.

Acknowledgments: We thank Edward Lowczowski from the Medical University of Lodz for editorial assistance. We are grateful to the patients, medical, nursing, and laboratory staff of the participating departments for their contributions to this study. 
Conflicts of Interest: Conflict of interest disclosure: R.J.K. is coinventor on the NIH patent for Moxetumomab Pasudotox. T.R. and A.J. received research grants from Medimmune and Astra Zeneca. K.J. and E.T. declare that they have no conflict of interest.

\section{References}

1. Grever, M.R.; Abdel-Wahab, O.; Andritsos, L.A.; Banerji, V.; Barrientos, J.; Blachly, J.S.; Call, T.G.; Catovsky, D.; Dearden, C.; Demeter, J.; et al. Consensus guidelines for the diagnosis and management of patients with classic hairy cell leukemia. Blood 2017, 129, 553-560. [CrossRef]

2. Robak, T.; Matutes, E.; Catovsky, D.; Zinzani, P.L.; Buske, C. ESMO Guidelines Committee. Hairy cell leukaemia: ESMO Clinical Practice Guidelines for diagnosis, treatment and follow-up. Ann. Oncol. 2015, 26, v100-v107. [CrossRef]

3. Smith, A.; Howell, D.; Patmore, R.; Jack, A.S.; Roman, E.P. Incidence of haematological malignancy by sub-type: A report from the Haematological Malignancy Research Network. Br. J. Cancer 2011, 105, 1684-1692. [CrossRef]

4. Teras, L.R.; DeSantis, C.E.; Cerhan, J.R.; Morton, L.M.; Jemal, A.; Flowers, C.R. 2016 US lymphoid malignancy statistics by World Health Organization subtypes. CA A Cancer J. Clin. 2016, 66, 443-459. [CrossRef]

5. Tiacci, E.; Trifonov, V.; Schiavoni, G.; Holmes, A.; Kern, W.; Martelli, M.P.; Pucciarini, A.; Bigerna, B.; Pacini, R.; Wells, V.A.; et al. BRAF mutations in hairy-cell leukemia. N. Engl. J. Med. 2011, 364, 2305-2315. [CrossRef]

6. Flinn, I.W.; Kopecky, K.J.; Foucar, M.K.; Head, D.; Bennett, J.M.; Hutchison, R.; Corbett, W.; Cassileth, P.; Habermann, T.; Golomb, H.; et al. Long-term follow-up of remission duration, mortality, and second malignancies in hairy cell leukemia patients treated with pentostatin. Blood 2000, 96, 2981-2986.

7. Goodman, G.R.; Burian, C.; Koziol, J.A.; Saven, A. Extended Follow-Up of Patients With Hairy Cell Leukemia After Treatment With Cladribine. J. Clin. Oncol. 2003, 21, 891-896. [CrossRef] [PubMed]

8. Zinzani, P.L.; Pellegrini, C.; Stefoni, V.; Derenzini, E.; Gandolfi, L.; Broccoli, A.; Argnani, L.; Quirini, F.; Pileri, S.; Baccarani, M. Hairy cell leukemia: Evaluation of the long-term outcome in 121 patients. Cancer 2010, 116, 4788-4792. [CrossRef]

9. Else, M.; Dearden, C.E.; Matutes, E.; Garcia-Talavera, J.; Rohatiner, A.Z.S.; Johnson, S.A.N.; O'Connor, N.T.J.; Haynes, A.; Osuji, N.; Forconi, F.; et al. Long-term follow-up of 233 patients with hairy cell leukaemia, treated initially with pentostatin or cladribine, at a median of 16 years from diagnosis. Br. J. Haematol. 2009, 145, 733-740. [CrossRef]

10. Kreitman, R.J.; Tallman, M.S.; Robak, T.; Coutre, S.; Wilson, W.H.; Stetler-Stevenson, M.; Fitzgerald, D.J.; Lechleider, R.; Pastan, I. Phase I Trial of Anti-CD22 Recombinant Immunotoxin Moxetumomab Pasudotox (CAT-8015 or HA22) in Patients with Hairy Cell Leukemia. J. Clin. Oncol. 2012, 30, 1822-1828. [CrossRef]

11. Kreitman, R.J.; Dearden, C.; Zinzani, P.L.; Delgado, J.; Karlin, L.; Robak, T.; Gladstone, D.E.; Le Coutre, P.; Dietrich, S.; Gotic, M.; et al. Moxetumomab pasudotox in relapsed/refractory hairy cell leukemia. Leukemia 2018, 32, 1768-1777. [CrossRef]

12. Kreitman, R.J.; Dearden, C.; Zinzani, P.L.; Delgado, J.; Robak, T.; le Coutre, P.D.; Gjertsen, B.T.; Troussard, X.; Roboz, G.J.; Karlin, L.; et al. Moxetumomab pasudotox in heavily pre-treated patients with relapsed/refractory hairy cell leukemia (HCL): Long-term follow-up from the pivotal trial. J. Hematol. Oncol. 2021, 14, 1-11. [CrossRef]

13. Tiacci, E.; Park, J.H.; De Carolis, L.; Chung, S.S.; Broccoli, A.; Scott, S.; Zaja, F.; Devlin, S.; Pulsoni, A.; Chung, Y.R.; et al. Targeting Mutant BRAF in Relapsed or Refractory Hairy-Cell Leukemia. N. Engl. J. Med. 2015, 373, 1733-1747. [CrossRef] [PubMed]

14. Dietrich, S.; Pircher, A.; Endris, V.; Peyrade, F.; Wendtner, C.-M.; Follows, G.A.; Hüllein, J.; Jethwa, A.; Ellert, E.; Walther, T.; et al. BRAF inhibition in hairy cell leukemia with low-dose vemurafenib. Blood 2016, 127, 2847-2855. [CrossRef]

15. Liebers, N.; Roider, T.; Bohn, J.-P.; Haberbosch, I.; Pircher, A.; Ferstl, B.; Ebnöther, M.; Wendtner, C.-M.; Dearden, C.; Follows, G.A.; et al. BRAF inhibitor treatment in classic hairy cell leukemia: A long-term follow-up study of patients treated outside clinical trials. Leukemia 2019, 34, 1454-1457. [CrossRef] [PubMed]

16. Kreitman, R.J.; Moreau, P.; Hutchings, M.; Gazzah, A.; Blay, J.-Y.; Wainberg, Z.A.; Stein, A.; Dietrich, S.; De Jonge, M.J.; Willenbacher, W; et al. Treatment with Combination of Dabrafenib and Trametinib in Patients with Recurrent/Refractory BRAF V600E-Mutated Hairy Cell Leukemia (HCL). Blood 2018, 132, 391. [CrossRef]

17. Tiacci, E.; De Carolis, L.; Simonetti, E.; Capponi, M.; Ambrosetti, A.; Lucia, E.; Antolino, A.; Pulsoni, A.; Ferrari, S.; Zinzani, P.L.; et al. Vemurafenib plus Rituximab in Refractory or Relapsed Hairy-Cell Leukemia. N. Engl. J. Med. 2021, 384, 1810-1823. [CrossRef] [PubMed]

18. Tiacci, E.; Schiavoni, G.; Forconi, F.; Santi, A.; Trentin, L.; Ambrosett, A.; Cecchini, D.; Sozzi, E.; Francia di Celle, P.; Di Bello, C.; et al. Simple genetic diagnosis of hairy cell leukemia by sensitive detection of the BRAF-V600E mutation. Blood 2012, 119, 192-195. [CrossRef]

19. Troussard, X.; Grever, M.R. The revised guidelines for the diagnosis and management of hairy cell leukaemia and the hairy cell leukaemia variant. Br. J. Haematol. 2021, 193, 11-14. [CrossRef]

20. Assanto, G.M.; Riemma, C.; Malaspina, F.; Perrone, S.; De Luca, M.L.; Pucciarini, A.; Annechini, G.; D’Elia, G.M.; Martelli, M.; Foà, R.; et al. The current role of interferon in hairy cell leukaemia: Clinical and molecular aspects. Br. J. Haematol. 2021. [CrossRef]

21. Habermann, T.M.; Rai, K. Historical treatments of in hairy cell leukemia, splenectomy and interferon: Past and current uses. Leuk. Lymphoma 2011, 52, 18-20. [CrossRef] 
22. Kreitman, R.J.; Tallman, M.S.; Robak, T.; Coutre, S.; Wilson, W.H.; Stetler-Stevenson, M.; Fitzgerald, D.J.; Santiago, L.; Gao, G.; Lanasa, M.C.; et al. Minimal residual hairy cell leukemia eradication with moxetumomab pasudotox: Phase 1 results and long-term follow-up. Blood 2018, 131, 2331-2334. [CrossRef] [PubMed]

23. Janus, A.; Robak, T. Moxetumomab pasudotox for the treatment of hairy cell leukemia. Expert Opin. Biol. Ther. 2019, 19, 501-508. [CrossRef] [PubMed]

24. Tiacci, E.; De Carolis, L.; Simonetti, E.; Merluzzi, M.; Bennati, A.; Perriello, V.M.; Pucciarini, A.; Santi, A.; Venanzi, A.; Pettirossi, V.; et al. Safety and efficacy of the BRAF inhibitor dabrafenib in relapsed or refractory hairy cell leukemia: A pilot phase-2 clinical trial. Leukemia 2021. [CrossRef]

25. Rogers, K.A.; Andritsos, L.A.; Wei, L.; McLaughlin, E.; Ruppert, A.S.; Anghelina, M.; Blachly, J.S.; Call, T.G.; Chihara, D.; Dauki, A.M.; et al. Phase 2 Study of Ibrutinib in Classic and Variant Hairy Cell Leukemia. Blood 2021. [CrossRef]

26. Shenoi, D.P.; Andritsos, L.A.; Blachly, J.S.; Rogers, K.A.; Moran, M.E.; Anghelina, M.; Jones, J.A.; Grever, M.R. Classic hairy cell leukemia complicated by pancytopenia and severe infection: A report of 3 cases treated with vemurafenib. Blood Adv. 2019, 3, 116-118. [CrossRef] [PubMed]

27. Bohn, J.P.; Pircher, A.; Wanner, D.; Vill, D.; Foeger, B.; Wolf, D.; Steurer, M. Low-dose vemurafenib in hairy cell leukemia patients with active infection. Am. J. Hematol. 2019, 94, E180-E182. [CrossRef]

28. Robak, E.; Jesionek-Kupnicka, D.; Iskierka-Jazdzewska, E.; Janus, A.; Robak, T. Cutaneous leukocytoclastic vasculitis at diagnosis of hairy cell leukemia successfully treated with vemurafenib and rituximab. Leuk. Res. 2021, 104, 106571. [CrossRef]

29. Moore, J.E.; Delibert, K.; Baran, A.M.; Evans, A.G.; Liesveld, J.L.; Zent, C.S. Targeted therapy for treatment of patients with classical hairy cell leukemia. Leuk. Res. 2021, 102, 106522. [CrossRef]

30. Smirnova, S.Y.; Al-Radi, L.S.; Moiseeva, T.N.; Gemdzhian, E.G.; Yakutik, I.A.; Julhakyan, H.L.; Novikov, V.A.; Galstyan, G.M.; Sudarikov, A.B. Inhibitor of BRAFV600E Mutation as a Treatment Option for Hairy Cell Leukemia With Deep Neutropenia and Infectious Complications. Clin. Lymphoma Myeloma Leuk. 2021. [CrossRef]

31. Burotto, M.; Stetler-Stevenson, M.; Arons, E.; Zhou, H.; Wilson, W.; Kreitman, R.J. Bendamustine and Rituximab in Relapsed and Refractory Hairy Cell Leukemia. Clin. Cancer Res. 2013, 19, 6313-6321. [CrossRef] [PubMed] 